\title{
Questioning what remains: A semiotic ap- proach to studying difficult monuments
}

\section{Mario Panico}

In Italy there is a difference between the historical experience of Fascism and what is remembered of it. In many cases, violence and repression have been interpreted as a kind of historical removal. In particular, the lack of the Nuremberg trial, as happened in Germany, allowed the traumatic memories of Mussolini's dictatorship to be banalized and made nostalgic. To understand these defects of Italian cultural memory, it may be useful to look at urban space. If urban space always speaks of something other than itself, then looking at the monumental traces of Fascism still standing in Italy allows to provide answers about the collective amnesia that has transformed Fascism into a parenthesis, as Benedetto Croce said in 1944. The main goal of this article is to investigate the mechanisms of conservation, a practice able to include new enunciations and remove old ones. In particular, through the analysis of some fascist monuments, I address four semiotic strategies of elaboration and cancellation of the past that weaken the sense of monumental representation. Specifically, I investigate the mechanisms of erasure, normalization, narcotization-latency and the construction of polyphonic memories.

\section{Keywords Monuments, Italian Fascism, Difficult Heritage, Cultural Memory}

\begin{abstract}
I spent the first twenty years of my life with Mussolini's face always in view, in the sense that his portrait was hung in every classroom, as well as in every public building or office.
\end{abstract}

Italo Calvino (2003: 207)

\section{Memory, urban space and difficult legacies}

The events that a social group decides to remember inevitably pass through urban narratives. Monuments, memorials and museums play an important strategic role in the construction of social identities and hegemonic power. 
In the last few decades, various scholars in the field of semiotics of cultural memory (e.g. Mazzucchelli 2010; Sozzi 2012; Bellentani and Panico 2016; Violi 2014, 2020) and cultural studies (e.g. Nora 1989; Assmann 1999; Kattago 2009) have dealt with the investigation of the spatial mechanism that allowed a bound transmission of the past and the elaboration of future imaginaries, compromising and questioning the relationship between individual and collective memories (Halbwachs 1925, 1950).

In this regard, the key point is that through spaces of memory specific social groups can self-represent, providing us with a clear image of what they perceive as a fundamental and strategic tool of communication, not only inside their own semiosphere, but also in the extra-semiotic space outside the boundaries of culture, facing what Lotman (1990: 128-129) defined as the barbaric space of others.

In this sense, urban space is 'a silent language, sometimes unaware of its own scope of meaning' (Marrone 2013: 13, my translation) that in any case enables a relationship between the story that is told on it and the subjective existences that run through it. Given that urban space as a semiotic language speaks about something other than itself (Greimas 1976), we can also assume that it speaks about the culture that thought, designed, built and then experienced it. This is possible, framing theoretically the points made thus far, because space is, in the words of Lotman (1984, 1990), culture uses a modelling language to describe itself, to situate itself topologically and subsequently to position all elements present in the cultural world.

As Patrizia Violi (2014: 23) has observed, this does not mean that urban space is merely a 'material landscape made of things', a pure material expression that is dislocated from the content that corresponds to it on the basis of pre-established cultural codes. On the contrary, urban space is a multifaceted and 'organized extension of things and people that constitute the plane of their expression, giving rise to a syncretic type of semiotics' (Violi 2014: 23, my translation), in which various systems and languages must be considered when setting the objective of deciphering its meaning. To do so requires adopting a perspective that can put aside the possible ontological extensions of urban spaces, or their geographical and architectural conformations, to give a wider reference to the way in which subjects question themselves through urban space and through different and mostly various discourses, and associate themselves to specific uses, functions or practices (Violi 2014: 23, my translation). Admitting this polyphony of languages, urban space therefore allows us to speculate (i) on the modalities adopted by subjects when hierarchizing the things of the world, as well as (ii) on their ability to invert these same cultural hierarchies, forgetting certain elements or producing counter-narratives.

In the case of monuments and memorials, this is evident because, on the one hand, they propose interesting reflections on the hegemonic re-written versions of history, and on the other, they put culture in front of the problem of elaborating what happened in the past. The latter case allows us to study how a culture might have to work on a textualization that it did not actually produce, rather received from a previous generation. 
What happens when the monuments under consideration relate to a traumatic past? The answer to this question is strongly tied to the notion of having to come to terms with a heritage that is already there and, from a certain moment on, that a culture has to deal with, interpret and critically re-evaluate in order to demonstrate at a national and international level that it has 'learned its lesson'. Here I consider that inherited heritage built during a dictatorship or a war in celebration of an authoritarian power. On this concern, some scholars speak about difficult heritage. This definition, which aims to be an umbrella term for 'heritage that hurts', such as 'dissonant heritage' or 'dark heritage' (see Tunbridge and Ashworth 1996; Sather-Wagstaff 2011; Koskinen-Koivisto 2016), was internationally legitimized for the first time in 2008 by the English anthropologist Sharon Macdonald. In her book entitled Difficult heritage. Negotiating the Nazi past in Nuremberg and beyond (2008) the scholar underlined the social role of buildings, monuments and urban traces as worthy of being remembered, restored and preserved due to the fact that they generate, in the culture in which they are inserted, a series of frictions, fears and diplomatic conflicts. More precisely, Macdonald wrote:

I call 'difficult heritage' [...] a past that is recognized as meaningful in the present but that is also contested and awkward for public reconciliation with a positive, self-affirming contemporary identity. "Difficult heritage" may also be troublesome because it threatens to break through into the present in disruptive ways, opening up social divisions, perhaps by playing into imagined, even nightmarish, futures. (Macdonald 2008: 1).

What should we do with the Nazi police headquarters in large German cities? What is the best way to convey traumatic memory without glorifying or normalizing its interpretation? What are the risks of granting these spaces the status of cultural heritage to be preserved, making them accessible to the public? Should we raze or re-functionalize the monuments erected at the behest or in honor of dictators? When a group opts for the second possibility, how can the past that belongs indexically to a space (Violi 2014) be re-semantized and critically evaluated, without feeding the myth of those who built it?

In the case of Nuremberg, the main case study considered by Macdonald, the answers to these questions find their coherence in a local and contextual point of view. The fact that Germany (both legally and culturally) had, at times, its semiotic sanction (Greimas and Courtés 1982: 267) with the Nuremberg process, should not be underestimated in a discourse on the re-functionalization of spaces. Having a year zero, a moment from which to start from scratch (actually more a complicated process of diplomatic reconciliation than a new, clear and peaceful beginning) allowed German culture to elaborate the errors of Nazism and interpret the past as traumatic, as something not to be forgotten in order to avoid the same mistakes ${ }^{1}$. Furthermore, it allowed Germany to divide responsibilities and share blame in urban space, propos- 
ing a clearer division of victims and perpetrators. As I said, at least institutionally, Nuremberg Trial represented a Sanction that allowed the semiotic definition of the actants within the conflict (Greimas and Courtés 1982: 5). The perpetrators of the Holocaust and of Nazi crimes were explicitly defined, as were the actant roles of its victims. This, precisely in relation to the self-representational capacity of urban space, was also made evident in the choices of heritage conservation and the representation of national faults and repentance. An example here is the headquarters of the Nazi police, the SS, in Munich, that today is a documentation center on National Socialism (NS-Dokumentationszentrum) focusing on the history of the city and Bavaria between the First and Second World Wars, with a particular focus on the political and social consequences of Nazism.

Sociological, anthropological and geographical literature on monuments and memorials has considered these spaces only as tools of power (see Sudjic 2005: 6), which convey particular messages and build identity, setting the agenda on hierarchies of values and on what can be represented or not. Macdonald (2008) problematizes this issue by adopting a different point of view, focusing less on construction than on conservation, hence maintaining a balance between past externalization and present elaboration in post-conflict situations. In doing so, the anthropologist shifts the temporal perspective and opposes the well-trod critical issue of identity constitution to the equally complex problem of the re-elaboration of one's past through what remains.

In this respect, monuments can be read as traces of an investigative cultural reflection. They constitute specific kind of signs that are installed in a culture as recognized marks (Eco 1976); they exist 'in a world of facts as a fact among facts, comes to be viewed by an addressee as the expression of a given content, either through a pre-existing and coded correlation or through the positioning of a possible correlation by its addressee' (Eco 1976: 221).

\section{Sign production for memory and forgetting}

All these theoretical premises will be tested in the context of the Italian landscape of memory. I will investigate different strategies that Italian culture adopted after the Second World War (hereafter WWII) to deal with the traumatic past. I will not assume a chronological or historical perspective. Using a semiotic perspective, I will propose different examples in order to consider various mechanisms of remembering and forgetting through urban space, from 'classical' erasure to critical preservation.

In this regard, these possibilities will be conceived - with necessarily theoretical adjustments - as modes of sign production à la Umberto Eco (1976: 151), which can also be interpreted as effective semiotic coping strategies that are capable of putting into urban space the forms of the elaboration of a traumatic collective past (see Mazzucchelli 2017). I firstly refer 
to (i) the modalities of erasure of the so-called high profile monuments connected to the two decades of Fascism in Italy; (ii) the fake neglecting of monuments in non-peripheral urban contexts; (iii) the modalities of a-historical reuse that do not consider the previous biography of the monuments; and (iv) ongoing forms of critical preservation of fascist monuments as artistic heritage, while polemically recognizing through challenging polyphonic enunciations the problematic meanings of their original design. These four possibilities do not represent simply a catalogue of interventions in post-conflict contexts, rather a literal metaphor, a sort of mirror through which is possible to reflect the emblematic memorial division of Italian culture on the themes of Fascism (see Foot 2009).

All of this bears in mind the fact that strategies of the preservation and reconstruction of monumental space always redefine the conceptual boundaries of what deserves representation, that is, visibility and memorability.

\section{The Italian landscape of memory}

The end of the WWII in 1945 produced a new spatial awareness related to what happened during the fascist Ventennio. Specifically, I am referring to acts of erasure, camouflage and re-writing proposed by the new-born country as forms of cultural translation that could say something more about the way in which public memories were selected, changed or removed and transmitted across generations.

The monumental traces of the fascist past in Italy, what remains of the 'environmental propaganda' (Nanni and Bellentani 2018: 390) set up under Benito Mussolini's regime, can be considered as mirrors of significance that can reflect translations of what the fascist past is and how it can still influence those social groups for which these monuments are the last living traces of a past political glory. In this sense, anticipating the case studies that follow, it is easy to understand how the monument "of the father visited upon the children" can trace a coherent reflection on the mechanism of elaboration of cultural identity. This is so precisely because 'space talks about society, it is one of the principal ways in which society portrays itself and represents itself as a meaningful reality' (Marrone 2001: 292, my translation) and - I might add - it consequently offers the coordinates for the transmission of the rewritten past in addressing the future. Furthermore, adopting a cultural semiotics perspective, I will propose through monuments certain answers about the collective amnesia that in contemporary Italy has transformed Fascism into what the Italian historian Benedetto Croce defined a 'casual parenthesis'2 rather than twenty traumatic years of a real and cruel dictatorship.

In 2017, Professor of Italian Studies and History at New York University Ruth Ben Ghiat wrote an eloquent editorial on the New Yorker on the spatial legacy of fascism in the Italian urban landscape. The emblematic title of her article - Why Are So Many Fascist Monuments 
Still Standing in Italy? - quickly became a sort of question-manifesto and a provocation on the hot topic of the urban legacy of Fascism. Ben Ghiat proposed a reasonable historical justification, saying that 'When Mussolini came to power, in 1922, he was leading a new movement in a country with a formidable cultural patrimony, and he knew that he needed a multitude of markers to imprint the fascist ideology on the landscape. Public projects, such as the Foro Mussolini sports complex, in Rome, were meant to rival those of the Medici and the Vatican, while the likeness of II Duce, as Mussolini was known, watched over Italians in the form of statues, photographs in offices, posters at tram stops, and even prints on bathing suits'.

Criticized by many Italian scholars and journalists who accused the American scholar of wanting to knock down all the monuments of the fascist era, Ben Ghiat's misunderstood provocation had a strong mediatic impact that transformed the topic of the 'maintenance' of fascist monuments in Italy into an ongoing public debate about identity representation and the preservation of what some parts of society see to be the country's artistic cultural heritage.

With the aim of pushing further Ben Ghiat's question, I would propose a change of perspective on, stressing attention not on why there are so many fascist monuments in Italy en plein air without any critical connection with their own past and origin, but on how they are still standing.

To be more specific, I am interested in how a certain forgetfulness manifests itself in the rewriting of memory in texts. My aim is to understand how a form of forgetfulness not only creates a new collective identity, in this case that of the Italians as 'not guilty' in the post-war landscape of memory, but also serves to weave new plots, absenting the crimes committed during the war. As Lotman (1990) has often explained in his work on memory and cultural self-representation, a specific culture bases the public representation of the collective self on the consolidation of a forgetfulness. The question therefore emerges of what a culture might select to forget, of how this can occur, and of who decides which events are forgettable.

After a traumatic event, culture - like a person's mind - tends to distance itself from traumatic events, which cannot be narrated since they are too difficult to process immediately. In the same way, in a collective dimension, for its own benefit culture seeks to filter those responsibilities that are too uncomfortable for diplomatic reasons, or those that would require a huge interpretational effort, for laziness or for political motives.

What is put into practice through these actions is a process of filtering, where what is considered uncomfortable is easily removed. The removal is activated through altered textualization practices, in which the dialogue with the past changes the meaning of the past itself, providing the next generations with a different and 'lighter' version of the story, that is easier to assimilate.

Furthermore, in these pages I propose a typology of the how fascist monuments produce a solid explanation of what Italian historians called rimozione (Pavone 2000: 21-22; Focardi 2013: XIX), referring to the process of removal (of guilt) inherent to the interpretations and, consequently, the legacy of the traumatic fascist past. As Hanna Malone writes in her historical reconstruction of the 'process of removal' in the space of Italian cities: 


\begin{abstract}
After liberation, the effects of 20 years of authoritarian rule, followed by a global war, a civil war and foreign military occupation, made it hard to implement any meaningful agenda of defascistisation. There was a sense that the memory of Fascism was too divisive and best forgotten. Plans to prosecute Fascist crimes and to purge public bureaucracy were soon abandoned on the grounds that they would destabilize the state and hinder the transition to democracy (Malone 2017: 448, my italics).
\end{abstract}

Furthermore, the revisionism that became diffuse at the end of the Cold War, after the fall of the Berlin Wall and the collapse of the Soviet Union, had various implications in Italy. One of this was a crisis in anti-fascism and the empowerment of various right-wing formations, including certain fascist-leaning parties. These political problems also had cultural consequences that remain traceable in the present. I refer in particular to the development of the Italiani Brava Gente stereotype (Italians the good people), widespread in public speeches as well as in cinema, promoting the idea that, during colonial campaigns, Italian fascist soldiers were 'kinder' than the German Nazis. Utilizing this international image, a process of purification of history was put in place, victimizing the Italians who in turn are interpreted as being forcedly involved-by-Nazis-by-Hitler and not guilty of war (see Focardi 2013). This re-interprets the fascist period as an unintentional event, for which the Italians have no responsibility since it merely fell out of the sky. All these facts contributed to the creation of a filtered imaginary in which is easier to speak of collective amnesia than collective memory (see Dondi 2001; Malone 2017; Arthus 2010).

\title{
Different ways to erase the recognizable
}

In Italy, the conservation modalities of the monuments that remained after the fascist era have not been uniform. There is not coherence in the preservation and conservation practices that depends significantly on local and regional governments characterized by different sensibilities and specific needs.

In this respect, the first typology of monumental elaboration that I consider is what has been labelled 'repressive erasure' by the social anthropologist Paul Connerton (2008). This refers to actions that seek the destruction of high-profile monuments which explicitly represent symbols related to power. In Seven types of forgetting, which outlines the different possibilities of memory erasure at a collective level, Connerton (2008) first refers to this kind of iconoclastic action also (and specifically) against monuments. In particular he writes: 
As the condemnation of memory (damnatio memoriae), it was inscribed in Roman criminal and constitutional law as a punishment applied to rulers and other powerful persons who at their death or after a revolution were declared to be 'enemies of the state': images of them were destroyed, statues of them were razed to the ground, and their names were removed from inscriptions, with the explicit purpose of casting all memory of them into oblivion (Connerton 2008: 60).

In line with this trend, after the Badoglio Armistice in 1943 which declared Italy's unconditional surrender to the Allies, the Italians decided to knock down power symbols in line with what happened across the world after a period of strong political authority. Specifically, monuments representing lictor fasces or the face/body of the dictator Benito Mussolini, i.e. the recognizable signs of Fascism, were torn down. It is evident that this episode of urban anger was a sort of symbolic ritual murder of the man and the ideology embodied in the stone of the monuments. This aspect poses a semiotic question regarding the relationship between monuments and political/cultural recognition. The attacked monuments were in fact urban signs that were assimilated from society (see for example the quote by Italo Calvino at opening of this article) and linked to a stable form of code. They occupied a specific place in the cultural imaginary so specific that, at the end of the dictatorship they end up becoming sign prostheses, extensions and at the same time material metonymy of the power that built them. In other words, the fascist lictors and the versions of Mussolini's face that were knocked down suffered this fate because of their high semiotic gradient, so high that their removal not only activated what we could easily expect, that is, a powerful erasure and an expulsion from the given semiosphere, but also a focus on the act of cancellation itself.

To offer an example, we might consider the fascist lictor removed in 1943 from the hand of the woman (symbolizing Victory) in the mosaic on the façade of the Galleria dei Legionari in Trento, a city in northern Italy (Figure 1).

Underneath there is a quote: Il popolo italiano ha creato col suo sangue l'impero lo feconderà col suo lavoro e lo difenderà contro chiunque con le sue armi (The Italian people have created the empire with their blood, they will fertilize it with their work, and they will defend it against anyone with their weapons). This is a quotation by Mussolini, whose name once appeared engraved alongside the words, but this too was removed like the fascist lictor. This operation certainly indicates an overcoming of values and a change in the semiotic coordinates of culture; at the same time, the shape of the symbol in stone left there as an imprint evokes the act of erasure and produces a clear presentification of absence.

In this sense, considering the afterlife of the fascist monument and its cultural legacy, removing the fascio littorio, with no further explanation or justification potentially enables nostalgic and dangerous attitudes towards the removed sign. The risk of this non-critical erasure lies in allowing this footprint to reactivate, inside certain predisposed groups, forms of yearn- 
ing for the past. In other words, the absent-but-visible fascio littorio could became the expression of a lost glory of the past, a sort of reminder that the nostalgic group can use to feed their needs and desire to restore the past. Alternatively, another possibility is that the absent sign merely becomes a form of failed damnatio memoriae where what is excluded is actually underlined, giving it a new emphasis and new visibility.

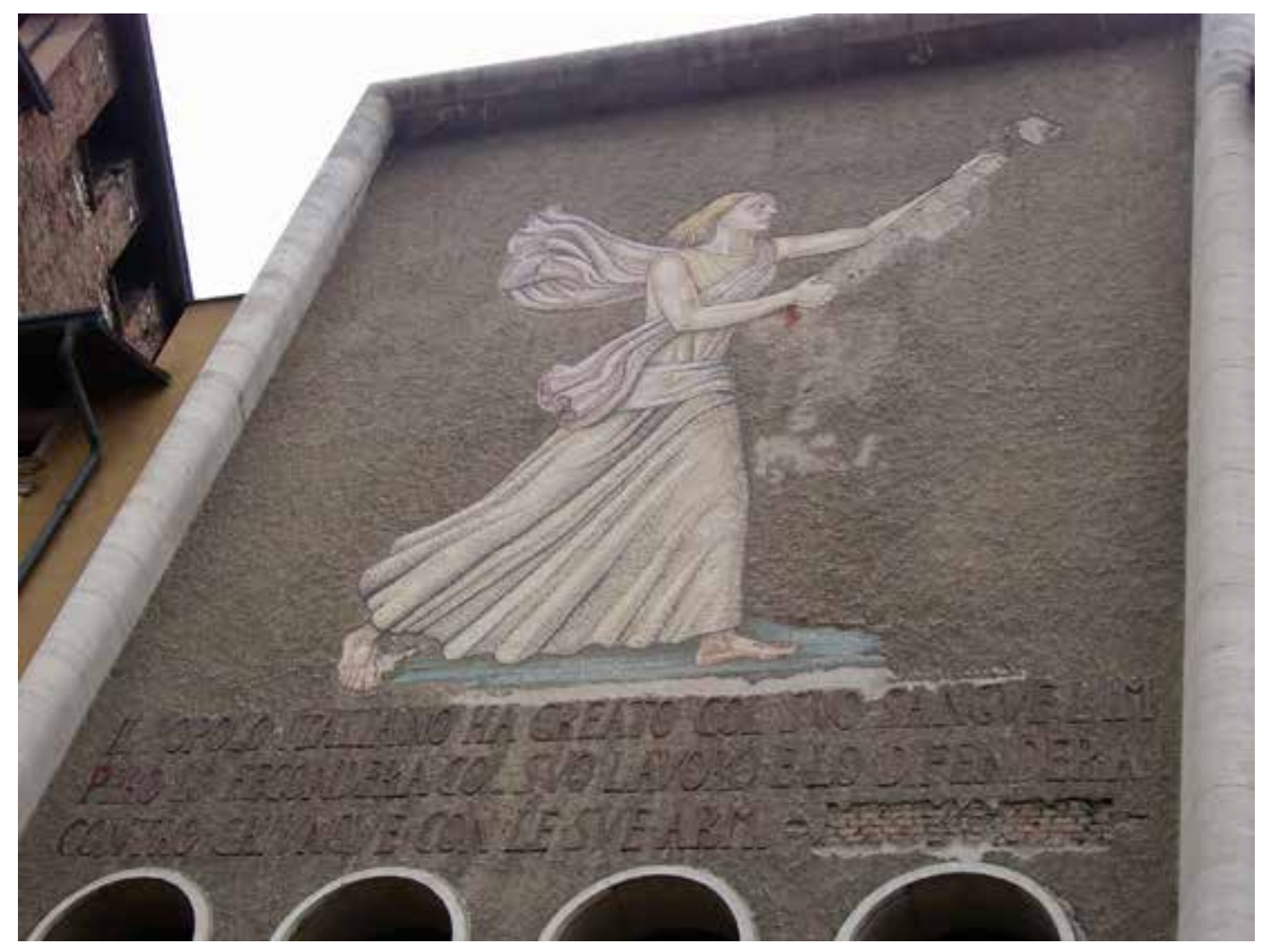

Figure 1: The façade of the Galleria dei Legionari in Trento - Photo courtesy of Henning Bulka

As Francesco Mazzucchelli wrote in 2017, questioning the way in which the semiosis could be interrupted: 'the destruction of the sign in its materiality does not always - or rarely, we dare say - negatively affect the propagation of its meaning, which can even survive the disappearance of material occurrence, translating and reactivating itself in other signs, and in some cases even proving to be enhanced. As all damnatio memoriae operations teach us - think of the forced removal of symbols at every change of political regime, revolutions, wars [...] - to eliminate the 'symbols' of the political adversary does not mean to cancel their semiotic presence' (Mazzucchelli 2017:111, my translation).

A different version of the same process of depotentiation is represented by the semantic 
recycling of monuments. This is precisely what happened to the statue of Mussolini on horseback that from 1929 sat at the Littoriale football stadium in Bologna, Italy (now named Stadio Renato Dall'Ara). After 1943 the statue was knocked down and decapitated during a mass protest, leaving the horse without a rider. Four years later in 1947, as though an act of metaphorical spatial revenge, the horse was melted down and re-made into another monument representing a man and a woman symbolizing the partisans. The monument was erected, where it stands still today, on the roundabout of Porta Lame in Bologna (Figure 2), where during WWII the Bolognese partisans fought and won a cruel battle against the Nazis (Storchi 2013).

This kind of removal is different from the one we dealt with previously in Trento because in this case no imprint of the previous life of this space was left behind. Only photographs and memories of the bolognesi who frequented the stadium during the fascist period can testify to the absence of Mussolini. In this case, we are faced with the case of a semiotic weakening in which the cancellation allows the narcotization of a precise portion of the knowledge of the past without anything to explicitly presentify its absence.

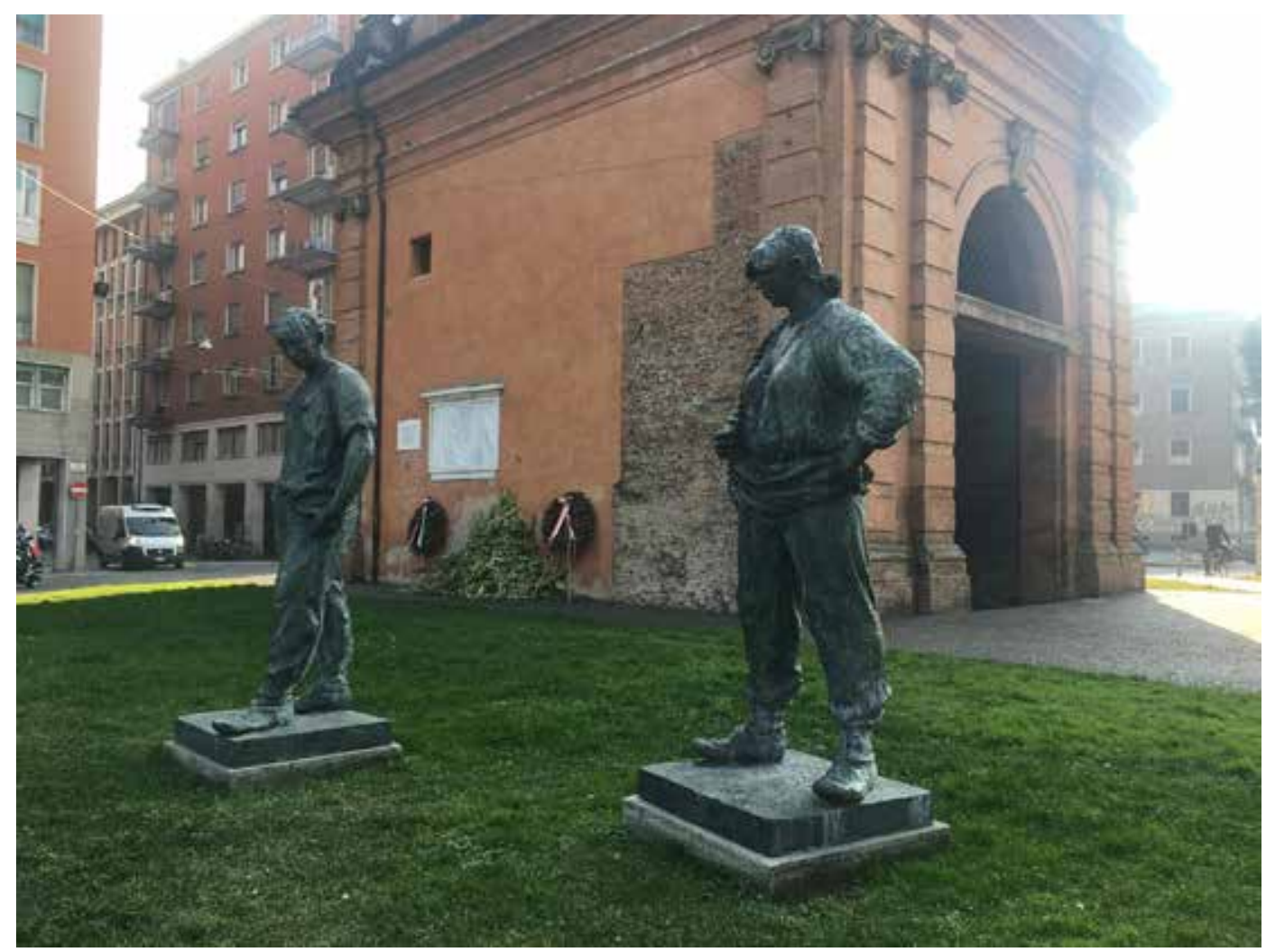

Figure 2: The monument of the two partisans in Bologna - Photo by the author 


\section{Grey zones and normalization}

Various scholarly works on monuments and their meanings in contemporary society open with a sentence by Robert Musil (1987: 61, my emphasis): 'Monuments possess all sorts of qualities. The most important is somewhat contradictory: what strikes one most about monuments is that one doesn't notice them. There is nothing in the world as invisible as monuments'. This sentence could be renewed and read from another perspective, starting from a question sub specie memorialis related to the legacy problems that this kind of indifference can produce.

A useful example that helps to dissolve any doubts in this regard can be found in the entire monumental complex of the Foro Italico in Rome, where still today there are mosaics on the pavement with fascist slogans such as Molti Nemici, Molto Onore (Many Enemies, Much Honor) or Duce Vi Dedichiamo La Nostra Giovinezza (Duce We Dedicate To You Our Youth), as well as an obelisk featuring, in fascist lettering, the surname of the former Italian dictator, accompanied by the Latin word Dux (Figure 3).

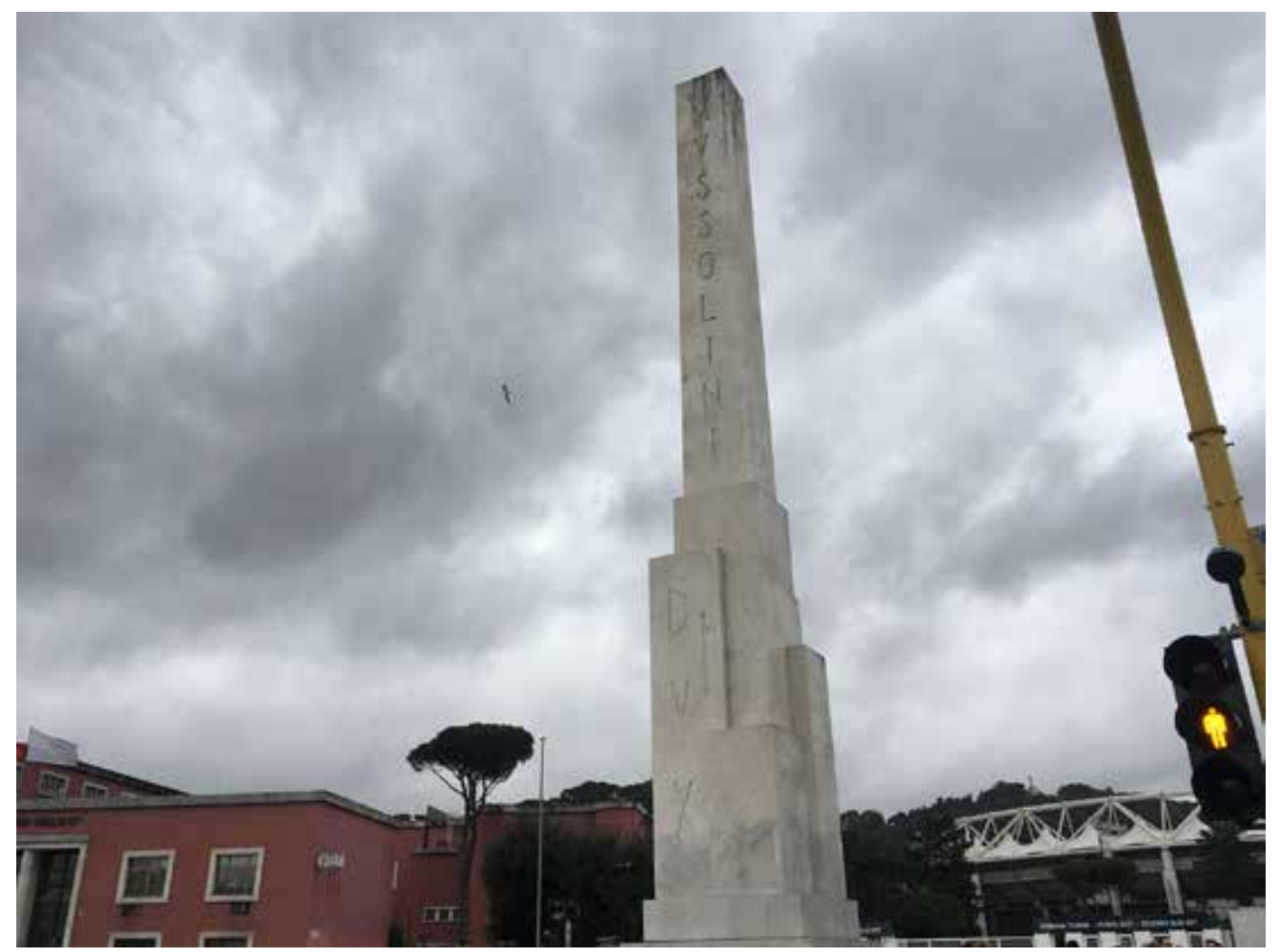

Figure 3: "Mussolini" obelisk in Rome - Photo by the author

The biography of the monument is a complex one: it was built as sport complex for the 
young fascists Balilla, after the war became a refuge for the allies and later, after years of neglect, the headquarters of the Italian Olympic Committee. The debate triggered by the former president of the Italian Chamber of Deputies, Laura Boldrini - who proposed during a commemoration for the $70^{\text {th }}$ anniversary of the Italian Resistance against Fascism in 2015 to erase the words Mussolini Dux from the obelisk - signals an interesting semiotic consideration related to different perceptions of the temporality of the monument.

If the removal could present an explicit cultural position, where the positioning of who decides to erase is explicit, here the situation is much more complex because both the monument and its creator merge in a sort of 'urban grey zone', in which the memory of what happened and that which is materialized by the monument are suspended. In particular following the observations by Mazzucchelli (2010: 304) about the liminal semantic space between 'not erasure' and 'not conservation', the Foro Italico declares an explicit 'incapacity for new elaboration'.

This grey zone, in which the semiotic role of the different actors interested in this urban representation are confused and overlap, efficiently represents (and not only metaphorically) the failure of memory elaboration in Italy. A comparison with the German context is inevitable: would it ever be possible to think of a monument existing still today in Germany with the name of Adolf Hitler?

Having a monumental complex in Rome where there are fascist sentences and symbols with no antifascist comments has led to its normalization, as Ruth Ben Ghiat stated during an interview in an Italian newspaper online: 'Fascist monuments are beautiful, but they remain monuments to violence, they are bloody buildings. The EUR was built in the years of the Axis, years of violence and aggression, against Jews, against anti-Fascists. In a world where the right is growing, such normalized symbolism encourages a vision of Fascism as something non-violent' (my translation).

In the contemporary context, the daily presence of the fascist symbol became a semiotic occurrence that determines a sort of repetition that allows consolidation and normalization. In this sense, the greatest risk is that the burden of the past is assimilated in a reductive way, where the uncritical preservation of the monument contributes to the standardization of the image of Benito Mussolini. Emptying the reference to the dictator of any meaning pushes the political values that characterized his life (when alive) into the background, overshadowed in favor of a pure form of expression, whereby the fascist monuments that are not re-functionalized in any way allow the creation of a system of values that 'feeds on contradictions and memorial simplifications' (Cole 2000). This kind of habit feeds new norms of remembrance, new shapes of memory that allow the creation, with a domino effect, of new memorial communities which in turn are strengthened by sharing and disseminating an imaginary that no longer exists in a strictly political sense. 


\section{Spatial narcotization and latency}

Maintaining a focus on monuments in Rome, I turn to another specific modality of the re-semantization of fascist monuments, looking at the Palazzo della Civiltà Italiana (Figure 4). The 'monument of the monument', as Mussolini called it, was designed in 1937 by the architects Giovanni Guerrini, Ernesto Bruno La Padula and Mario Romano for various reasons: to glorify the Italian colonialist campaigns in Africa, to host the Mostra della Civiltà Romana on the occasion of the universal exposition E42, which was due to take place in Rome on the commemoration of the twentieth anniversary of the foundation of the fascist regime in Italy, but never ultimately inaugurated due to the outbreak of WWII.

Without considering all the different uses of this monument after WWII, and the lengthy periods when it was abandoned, it is worth considering in detail its history from 2013 onward, when the luxury fashion brand Fendi decided to rent the space, transforming it into its new global headquarters.

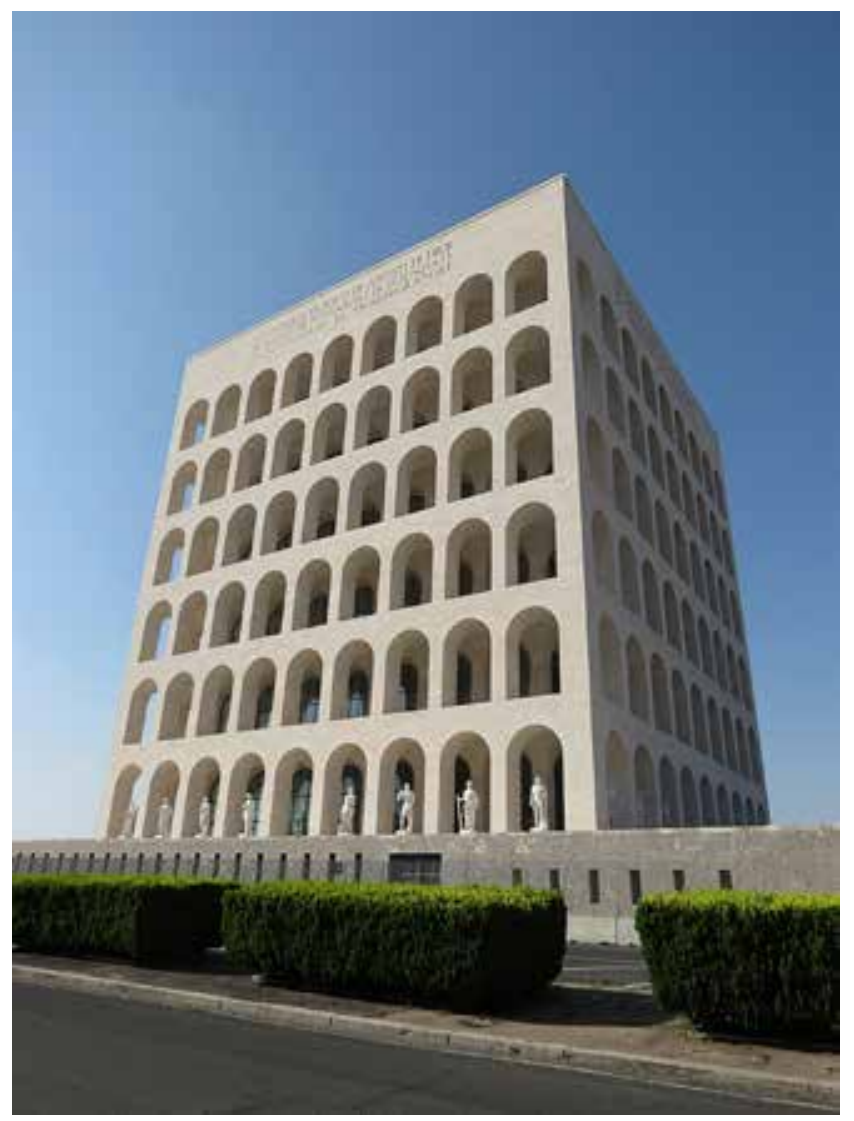


The semiotic relevance of this event is not the change in usability of the space but the fact that Fendi decided to ignore any connection to the previous life of the monument. The fashion brand decided not to change anything on the level of the expression of the monument because, paraphrasing the company's response to some criticism in this direction, this building is the symbol of ancient Roman roots that finally came back to the city (Fiorentino 2015 in Malone 2017: 458).

From a memory perspective, this statement produces what I would call a trivialization of the traumatic past of which the Palazzo della Civiltà is a contemporary witness. To understand this aspect, suffice it to focus our attention on the sentence present on the top of all four sides of what the Romans nicknamed as the square colosseum: Un popolo di poeti di artisti di eroi di santi di pensatori di scienziati di navigatori di trasmigratori (A population of poets artists heroes saints thinkers scientists navigators transmigrators). While, today, Fendi has changed the semiotic meanings of this sentence, transforming it (without altering a word) into an exaltation of made in Italy products, it was actually first pronounced by Mussolini in 1935, in a speech in which he announced the invasion of Ethiopia, during the Italian colonialist campaigns before the start of the WWII.

Following Greimas (1976), the Enunciator and the Enunciatee change, but not the utterance. From the subject of an enunciation that directed his spatial and literal message to a 'Fascist and Italian' Enunciatee, after Fendi's arrival, this shifts to a collective Sender, the fashion house, that through an act of re-appropriation and contemporary narcotization requalifies the sentence, nevertheless obliging the previous intentions of the monument's design. This memorial lack leads the building itself to a reconversion which, on a collective and cultural level, proposes a political weakening followed by the production of a form of amnesia.

Fendi's re-appropriation of a fascist space leaves Fascism itself in a form of encyclopedic latency ${ }^{3}$. Following the theory of forgetfulness and latency proposed by Umberto Eco in From the tree to the labyrinth (2014), the monument's references to Fascism are not erased through an explicit act of sign destruction (see Mazzucchelli 2017), but redirected in an even more misleading way, changing their narrative structure. This is therefore, once again borrowing an image proposed by Eco (2014: 88), frozen information, certainly not a definitive erasure, rather 'all the expert has to do is to take it out of the freezer and put it in the microwave to make it available once again, at least as much as is needed to understand a given context' (Eco 2014: 88). This means that, given the narcotizing action proposed by Fendi, the Mussolini monument becomes a 'tool for forgetting, or at least for rendering something latent' (Eco 2014: 89). This 'something', however, in our case has some gravity, representing a part of history that, also due to this kind of action, has often been minimized, in favor of a revisionism that has exalted its presumed positive aspects: for example, the undisputed architectural and artistic value of the monument.

By linking our reasoning to semiotic theory, we can recall an interesting passage from Eco in which he deals with the production of textual forgetfulness: 
If in a semiotics the correlation is not based on simple automatic equivalence $(a=b)$, but on a principle of inferentiality, however elementary (if $a$, then b), the meaning of an expression is a potentially huge package of instructions for interpreting the expression in different contexts and drawing from it, as Peirce would have it, all the most remote inferential consequences, in other words, all its interpretants. On these bases we ought then to know in theory every possible interpretant of an expression, whereas in practice we know (or remember) only the portion that is activated by a given context (Eco 2014: 90).

Following Eco, Fendi's custody of the building, while making it understandable as something more than a monument, at the same time narcotizes its entire past biography, thus avoiding the chance to work through or challenge it. By avoiding conflict and weakening its fascist aspect, the form of narcotization that emerges does not simply put aside a portion of the building's story. What is semiotically interesting here is that the rhetoric adopted by Fendi to justify the reinvigoration of this building is essentially the same as the rhetoric that Mussolini used in this spatial mediator (Assmann 1999) which communicated his idea of fascist greatness. Fendi seems to clean up all previous interpretations, entrusting the monumental space with a new year zero, leaving its external surface unchanged, without referring to the intentions of the original design. Fendi's action, perhaps unconscious, was that of encyclopedical mixing, making it increasingly difficult to elaborate a form of collective guilt for what happened during the fascist colonial campaigns in Africa. By changing the dynamics of the actors, even the so-called Model Readers (Eco 1979) of the monument are no longer the same: we have passed from the 'fascist' to the 'proud Italian', generating a link between the Roman Empire and the contemporary world that does not contemplate the degree of separation represented by the fascist Ventennio.

As mentioned above, this re-semantization is a form of temporary and transitory forgetfulness 'a side effect, due to reasons of interpretative economy' (Eco 2014: 95). No sooner than a semiotic connection with the monument's fascist past is reactivated, this part of history, which the new translation has tried to bury, is made manifest. This happened, for example, during a student event organized by a far-right student group, Lotta Studentesca, which in the posters used to promote the parade used the image of the square colosseum (Malone 2017: 459); or, again, when the fashion brand Pivert, favored by the extreme-right militants of Casa Pound and Forza Nuova, chose the monument for its press campaign. Another example comes from strict politics: in 2019, Giorgia Meloni, leader of the right-wing party Fratelli d'Italia, decided to nominate Benito Mussolini's great-grandson Caio Giulio Cesare Mussolini for the European elections. She presented the candidate publicly through a web-video stream, where the two appeared in front of the square coliseum (see Violi 2020). All of these examples bring the meaning of monument's design back to the present, without, however, any anti-fascist counter-reflection. If in the case of 
Fendi the interpretation of the monument is inclined to 'Italianness' with no consideration of the fascist violence that is textualized within it, in the case of the re-appropriations from the right or the pro-fascist culture the original design's meaning is resumed.

\section{Polyphonic memories in the same monument}

An example of how a polyphonic and anti-fascist statement can be put into space comes from Bolzano, a city in the North of Italy close to the national border with Austria. I refer to the fascist bas-relief made by the artist Hans Piffrader which was strangely located after the war, in 1957, on the former fascist headquarters in the city that today is home to several administrative institutions. The plaque represents Benito Mussolini on horseback in the middle, accompanied by the words engraved in the stone Credere Obbedire Combattere (Believe, Obey, Fight). In 2017, the municipality of Bolzano decided to add a large bright neon sign in white that reads, in the three languages of the city (Ladin, Italian and German), No one has the right to obey ${ }^{4}$ a quotation of the Jewish philosopher Hannah Arendt (Figure 5).

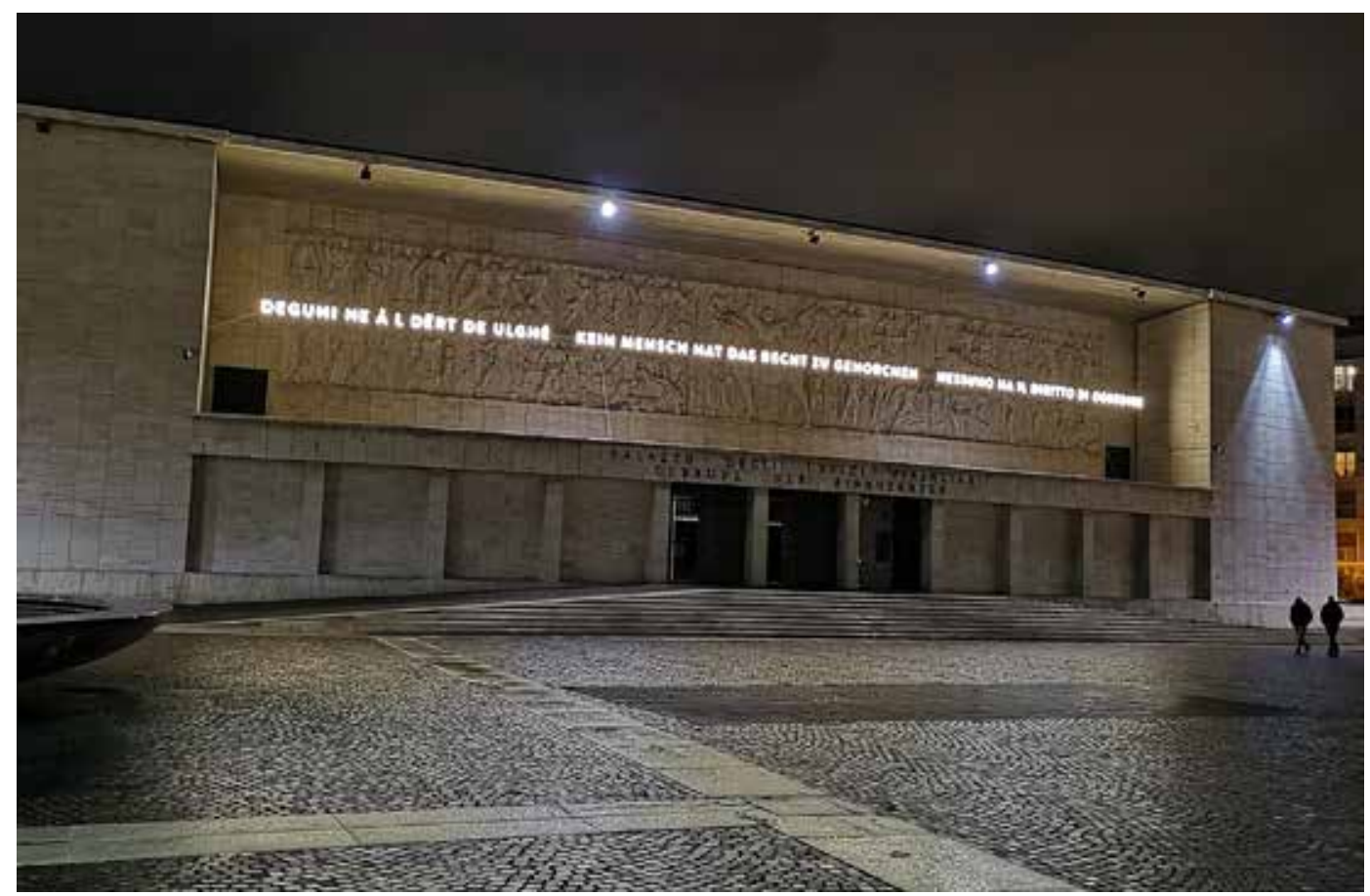

Figure 5: The bas-relief of Mussolini with the sentence by Hanna Arendt (source: @Bartleby08 via Wikipedia)

This last example opens the door to a very different reflection to those conducted so far. What was produced in Bolzano is a clear example of what scholars of memory and museum 
studies have called 'critical preservation' (see Carter and Martin 2019). Conceived and theorized with reference to the Nazi heritage of Germany, critical preservation concerns those modes of polemical elaboration of difficult heritage that aim neither to destroy nor to neutralize it, rather to create a structure of polyphonic spatial enunciation, in which the original meaning of the design (in this case a fascist one) is made to communicate with an Enunciation of opposite political tones and values, creating a sort of polemical spatial structure that is constantly under the eyes of the public.

In the Bolzano case considered, this oppositional structure is created with respect to a semantic overturning that is spatially produced through the anti-fascist conversion of the word obey. If in Mussolini's bas-relief there was an exhortation to military action and obedience, Arendt's words, which even topologically are placed 'upon' the former, as a rewriting and subversive stratification, focus on the denial of unconditional obedience to any hegemonic power. Following Violi's reflection, this gesture of overlap generates the possibility of the rhetoric coexistence of competing messages: 'that of the monument and that of Arendt's words, thematically opposed but kept within the same frame. The effect is a polyphonic text with two voices, in which neither completely erases the other; their juxtaposition determines by contrast a further level of meaning, a stratified historical thickness' (Violi 2020, my translation).

Those levels that articulate two perspective follow a specific narrative model that opposes each of them to an antagonist, in the sense that the semantic values that are transmitted are related to value that carry a contrastive relation. This does not neutralize rather depoliticizes it, or more precisely, defascistizes the totalitarian ideology through its democratic re-politicization. Two statements compete simultaneously in space, in a sort of 'materic hand-to-hand' (Violi 2020, my translation), generating a narrative conflict and feeding an articulate response to the historical gap produced in post-fascist Italy.

\section{Conclusion: Notes on cultural silence}

Another element that should not be underestimated when dealing with the translation of memories though difficult monuments is their transmission to new generations. This type of reflection allows us to link the famous concept of postmemory proposed by Marianne Hirsh (2012) with what in Italy can be called a generational removal of memory, which has not only produced a particular form of forgetfulness but has enabled an alternative narrative, proposed by forgetfulness, to become a cultural norm. In this sense, silence actually becomes a semiotic noise, a rhetorical tool that does not eliminate communication as it would hope to. In losing its ontological nature, by proposing an alternative communication mediator for what has been set aside in the historical narrative, silence makes what is in the latent murmur intelligible.

This imposition of silence has found a privileged channel in Italy because, as the Italian 
sociologist Paolo Jedlowski (2011) has written, there has never been a solid relationship between memory and justice in this country, because of an evidently different way of processing and elaborating the traumatic past. This is due to the fact that there was never a distinction made between those who could be considered perpetrators and those who were part of the antifascist faction. This lack of definition of semiotic actor-roles prevented a clear and well-defined interpretation of the past, at least at legal level.

As a consequence, the role of silence in the transmission of memory has imposed cultural amnesia, a false cultural memory, in which what is erased has become more important than what is explicitly represented. In other words, that imaginary of Italian Fascism as a light dictatorship was in part propagated in this landscape of silent memory, between unawareness and a delay in the necessary processing of the dictatorial past.

\section{NOTES}

1 I will not attempt to consider all the specificities of Nazi heritage. It is important to point out, however, that Germany is also an emblematic case because even before the Nuremberg trial, many Nazi monuments and buildings had been destroyed by the Soviet and American armies. 2 On Fascism as a parenthesis, I refer to Benedetto Croce's speech at the first CLN (Comitato di liberazione nazionale) in Bari, January 1944, published in Croce (1993: 61).

3 On this occasion, I borrow the concept Encyclopedia from Umberto Eco. The semiotician considered it as the repertoire of all textualized knowledge and all interpretations, as the entirety of the already-said. Using the words of Eco, the Encyclopedia 'is the recorded set of all interpretations, objectively conceivable as the library of libraries, where a library is also an archive of all non-verbal information recorded in some way, from rock paintings to film libraries' (Eco 1984: 109, my translation).

4 The quotation chooses for the monument is taken from interview of Arendt given to Joachim Fest in 1964, after the publication of her book on Eichmann.

\section{REFERENCES}

Assmann, Aleida 1999. Erinnerungsraüme. Formen und Wandlungen des kulturellen Gedächtnisses. München: Oskar Beck.

Arthus, Joshua 2010. Fascism as 'heritage' in contemporary Italy. In: Mammone Andrea and Giuseppe A. Veltri (eds) Italy Today: The sick of man of Europe. London: Routledge, 114-128. 
Bellentani, Federico and Mario Panico 2016. The meaning of monument and memorials: Toward a semiotic approach. Punctum. International Journal of Semiotics 2 (1): 28-46.

Ben Ghiat, Ruth 2017. Why Are So Many Fascist Monuments Still Standing in Italy? The New Yorker, October 5.

Calvino, Italo 2003. Hermit in Paris: Autobiographical writings. New York: Pantheon Books.

Carter, Nick and Simon Martin 2019. Dealing with difficult heritage: Italy and the material legacies of Fascism. Modern Italy 24 (2): 117-122.

Cole, Tim 2000. Selling the Holocaust: From Auschwitz to Schindler: How history is bought, packaged and sold. London and New York: Routledge.

Connerton, Paul 2008. Seven types of forgetting. Memory Studies 1 (1): 59-71.

Croce, Benedetto 1993. Scritti e discorsi politici (1943-1947). Vol. I. Edited by Angela Carella. Naples: Bibliopolis.

Dondi, Mirco 2001. The Fascist mentality after Fascism. In: Richard J.B. Bosworth and Patrizia Dogliani (eds) Italian Fascism: History, memory, representation. New York: St Martin's Press, 141-160.

Eco, Umberto 1976. A theory of semiotics. Bloomington: Indiana University Press.

Eco, Umberto 1979. The role of the reader. Explorations in the semiotics of texts. Bloomington: Indiana University Press.

Eco, Umberto 1984. Semiotica e filosofia del linguaggio. Milan: Bompiani.

Eco, Umberto 2014. From the tree to the labyrinth. Historical studies on the sign and interpretation. Cambridge: Harvard University Press.

Focardi, Filippo 2013. Il cattivo tedesco e il bravo italiano. La rimozione delle colpe della seconda guerra mondiale. Rome and Bari: Laterza.

Foot, John 2009. Italy's divided memory. New York: Palgrave Macmillan.

Greimas, Algirdas Julien 1976. Pour une sémiotique topologique. In: Sémiotique et sciences sociales. Paris: Editions du Seuil, 129-157.

Greimas, Algirdas Julien and Joseph Courtés 1982. Semiotics and language: An analytical dictionary. Bloomington: Indiana University Press.

Halbwachs, Maurice 1925. Les cadres sociaux de la mémoire. Paris: Librairie Félix Alcan.

Halbwachs, Maurice 1950. La mémoire collective. Paris: Presses Universitaires de France.

Hirsh, Marianne 2012. The generation of postmemory: Writing and visual culture after the Holocaust. New York: Columbia University Press.

Jedlowski, Paolo 2011. Memoria pubblica e colonialismo italiano. Storicamente (7) [online] Kattago, Siobhan 2009. War Memorials and the Politics of Memory: The Soviet War Memorial in Tallinn. Constellation 16 (1): 150-166.

Koskinen-Koivisto Eerika 2016. Reminder of the dark heritage of humankind. Experiences 
of Finnish cemetery tourists of visiting the Norjvajärvi German cemetery. Thanatos 5 (1): 23-42.

Lorusso, Anna Maria 2014. Cultural semiotics: For a cultural perspective in semiotics. New York: Palgrave Macmillan.

Lotman, Juri Michajlovič 1984. O semiosfere [The semiosphere]. Trudy po znakovym sistemam 17: 5-23.

Lotman, Juri Michajlovič 1990. Universe of the mind. A semiotic theory of culture. London and New York: I.B. Tauris.

Macdonald, Sharon 2008. Difficult heritage: Negotiating the Nazi past in Nuremberg and beyond. London and New York: Routledge.

Malone, Hannah 2017. Legacies of Fascism: architecture, heritage and memory in contemporary Italy. Modern Italy 22 (4): 445-470.

Marrone, Gianfranco 2001. Corpi sociali. Processi comunicativi e semiotica del testo. Turin: Einaudi.

Marrone, Gianfranco 2013. Figure di città. Udine and Milan: Mimesis.

Mazzucchelli, Francesco 2010. Urbicidio. Il senso dei luoghi tra distruzioni e ricostruzioni nella ex Jugoslavia. Bologna: Bononia University Press.

Mazzucchelli, Francesco 2017. Modi di distruzione segnica. Come si arresta la semiosi?. Versus. Quaderni di Studi Semiotici 124 (1): 105-128.

Musil, Robert 1987. Posthumous papers of a living author. Hygiene: Eridanos Press, 61-64.

Nanni, Antonio and Federico Bellentani, 2018. The meaning making of the built environment in the fascist city: A semiotic approach. Signs and Society 6 (2): 379-411.

Nora, Pierre 1989. Between memory and history: Les lieux de mémoire. Representations $26:$ 7-24.

Pavone, Claudio 2000. Negazionismi, rimozioni, revisionismi: storia o politica?. In: Enzo Collotti (ed) Rimozioni, revisioni, negazioni. Rome: Laterza, 15-42.

Sather-Wagstaff, Joy 2011. Heritage that hurts. Tourists in the memoryscapes of September 11. Walnut Creek: Left Coast Press.

Storchi, Simona 2013. Mussolini as monument: The equestrian statue of the Duce at the Littoriale Stadium in Bologna. In: Stephan Gundle, Christopher Duggan and Giuliana Pieri (eds) The cult of the Duce: Mussolini and the Italians. Manchester: Manchester University Press, 193-208.

Sozzi, Paola 2012. Spazio, memoria e ideologia. Analisi semiotica del Sacrario Monumentale di Cime Grappa. E/C. Rivista dell'Associazione Italiana di Studi Semiotici: 1-23.

Sudjic, Deyan 2005. The edifice complex: How the rich and powerful shape the world. London: Allen Lane.

Tunbridge, John E. and Gregory Ashworth 1996. Dissonant heritage. The management of the past as a resource in conflict. Chichester: John Wiley and Sons. 
Violi, Patrizia 2014. Paesaggi della memoria. Il trauma, la storia, l'oblio. Milan: Bompiani.

Violi, Patrizia [forthcoming 2020]. Eredità difficili: I monumenti del fascismo nell'Italia di oggi. In: Enrico Garavelli, Daniele Monticelli, Ülar Ploom and Elina Suomela-Härmä (eds), Italianistica 2.0. Tradizione e innovazione. Atti del XII congresso degli Italianisti della Scandinavia. Helsinki: Société Néophilologique de Helsinki.

Mario Panico holds a PhD in Philosophy, Science, Cognition and Semiotics, University of Bologna, Italy.

Email: mariopanico21@gmail.com 